\title{
Reaction Behaviors of Associated Minerals in Molten Salt Smelting of Stibnite and Kilogram-Class Trials
}

\author{
Zhen Ouyang ${ }^{1}$, Longgang Ye ${ }^{1, *}$, Chaobo Tang ${ }^{2}$ and Yuntao Xin ${ }^{3}$ \\ 1 College of Metallurgyand Material Engineering, Hunan University of Technology, Zhuzhou 412007, China; \\ oyz951002@163.com \\ 2 School of Metallurgy and Environment, Central South University, Changsha 410083, China; \\ tangchaobo9043@163.com \\ 3 College of Materials Science and Engineering, Chongqing University, Chongqing 400044, China; \\ xinyuntao@cqu.edu.cn \\ * Correspondence: yelonggang@sina.cn; Tel./Fax: +86-0731-22183453
}

Received: 18 November 2019; Accepted: 21 December 2019; Published: 25 December 2019

\begin{abstract}
The molten salt metallurgy of $\mathrm{Sb}$, which involves the smelting of stibnite in a binary $\mathrm{NaCl}-\mathrm{Na}_{2} \mathrm{CO}_{3}$ salt with sulfur-fixing and the addition of a reductant, has been proposed as a clean method for $\mathrm{Sb}$ extraction. However, the reacting behaviors of the minerals associated with stibnite $\left(\mathrm{Sb}_{2} \mathrm{~S}_{3}\right)$ during the smelting are still unclear, and industrial tests have not been conducted. This study investigated the behaviors of $\mathrm{PbS}, \mathrm{FeS}_{2}, \mathrm{SiO}_{2}$, and $\mathrm{CaCO}_{3}$, which are the main minerals associated with stibnite, during reducing smelting by using the $\mathrm{NaCl}-\mathrm{Na}_{2} \mathrm{CO}_{3}$ molten salt. The results showed that $\mathrm{PbS}$ could react with $\mathrm{Na}_{2} \mathrm{CO}_{3}$ to generate metallic $\mathrm{Pb}$ at $950{ }^{\circ} \mathrm{C}$. $\mathrm{FeS}_{2}$ and $\mathrm{SiO}_{2}$ formed stable $\mathrm{NaFeS}_{2}$ and $\mathrm{Na}_{2} \mathrm{SiO}_{3}$ with the molten salt at a high temperature, respectively. $\mathrm{CaCO}_{3}$ formed an unstable intermediate product of $\mathrm{Na}_{2} \mathrm{Ca}\left(\mathrm{CO}_{3}\right)_{2}$ at $675{ }^{\circ} \mathrm{C}$ and decomposed with increasing temperature. Kilogram-class trials were also performed using $50 \mathrm{~kg}$ of concentrate and more than $300 \mathrm{~kg}$ of mixture material, and the results showed that the direct recovery rate of $\mathrm{Sb}$ and Au reached maximum values of $93.22 \%$ and $92.06 \%$ at temperature $920{ }^{\circ} \mathrm{C}$ in eutectic $\mathrm{Na}_{2} \mathrm{CO}_{3}-\mathrm{NaCl}$ molten salt, respectively, while the total sulfur-fixing ratio reached $99.49 \%$. Thus, the associated minerals consumed the molten salt, and the feasibility of molten salt smelting was verified by this kilogram-class pilot experiment.
\end{abstract}

Keywords: molten salt; antimony metallurgy; thermodynamic; TG-DTA; stibnite

\section{Introduction}

$\mathrm{Sb}$ is mainly used for manufacturing alloys, semiconductor optoelectronic devices, and $\mathrm{Sb}$ compounds [1,2]. More than $80 \%$ of the world's Sb is produced in China [3]. Stibnite $\left(\mathrm{Sb}_{2} \mathrm{~S}_{3}\right)$ and jamesonite $\left(\mathrm{Pb}_{4} \mathrm{FeSb}_{6} \mathrm{~S}_{14}\right)$ are the two main raw ores used for $\mathrm{Sb}$ smelting [3,4], and a pyrometallurgical process is the primary method used to extract $\mathrm{Sb}$. Smelting under high temperatures (1100-1350 ${ }^{\circ} \mathrm{C}$ ) has many shortcomings, including the consumption of large amounts of energy and materials, the consumption of refractory materials, and environmental pollution from the volatilization of $\mathrm{Pb}$ and As, as well as a low concentration of $\mathrm{SO}_{2}$, it cannot be used to make acid and required plenty of alkaline solution for absorption. At present, the research on green $\mathrm{Sb}$ extraction includes hydrometallurgical and pyrometallurgical processes. In the field of hydrometallurgy, $\mathrm{NaOH}$ and $\mathrm{Na}_{2} \mathrm{~S}[5,6]$ have been investigated as leaching agents to leach $\mathrm{Sb}$ sulfide ore, after which the $\mathrm{Sb}$ metal can be obtained by electrolysis. This method has been attributed to alkaline leaching. In addition, acidic agents, including $\mathrm{SbCl}_{5}-\mathrm{HCl}$ and $\mathrm{FeCl}_{3}-\mathrm{HCl}$ [7-10], have been used to leach $\mathrm{Sb}$ sulfide ore, after which $\mathrm{Sb}$ was produced using diaphragm electrowinning. A low current efficiency and serious equipment corrosion were the 
main barriers in this hydrometallurgical process. At present, only a few plants have adopted it to produce $\mathrm{Sb}$ white.

In the field of pyrometallurgy, intensified smelting, using oxygen enrichment as an oxidant, was proposed to improve the traditional $\mathrm{Sb}$ extraction process [11-13]. These methods can improve the $\mathrm{SO}_{2}$ concentration in the flue gas and allow it to meet the acid production requirement. But the problems of flue bonding and the dispersion of valuable metals remain unsolved. Currently, many $\mathrm{Sb}$ smelteries are small, the acid-making process is a large investment for them. Therefore, sulfur-fixing roasting and smelting based on the difference between the sulphophile affinity of $\mathrm{Sb}$ and those of other metals were investigated. Padilla $[14,15]$ researched the carbon reduction of stibnite to produce $\mathrm{Sb}$ oxide and metallic $\mathrm{Sb}$ using $\mathrm{CaO}$ as a sulfur-fixing agent. This method solved the problem of $\mathrm{SO}_{2}$ flue gas pollution in the traditional process. While the separation of the calcium sulfide and $\mathrm{Sb}$ produced by the reaction is difficult, and calcium sulfide is not easy to recover and utilize. Thus, sulfur-fixing had the advantage of free $\mathrm{SO}_{2}$ emission, and the low-temperature and short-process extraction was also an important development in pyrometallurgy. Smirnov [16] first proposed alkaline smelting in molten $\mathrm{NaOH}$ to extract $\mathrm{Pb}$ from $\mathrm{PbS}$ ore at low temperatures of $400-900^{\circ} \mathrm{C}$. Margulis [17] also adopted molten $\mathrm{NaOH}$ to smelt metallic $\mathrm{Pb}$ scrap at $400{ }^{\circ} \mathrm{C}$. The outstanding advantages of this process were its low temperature, work condition improvement, and reduction of flue gas emissions ( $95 \%$ less than the conventional process).

In the previous alkaline smelting, no sulfur-fixing agent was added, and a single $\mathrm{NaOH}$ molten salt was used. Thus, the $\mathrm{NaOH}$ participated in the reactions and could not be recovered. Additionally, because the molten salt exhibited excellent properties, including good thermal stability and conductivity $[18,19]$ and a low melting point, it has been widely applied in molten salt electrolysis and solar power cells $[20,21]$. Therefore, our team investigated a sulfur-fixing smelting method, in which $\mathrm{Sb}$ sulfide was smelted in an $\mathrm{NaCl}-\mathrm{Na}_{2} \mathrm{CO}_{3}$ binary molten salt with $\mathrm{ZnO}$ added as a sulfur fixing agent. Sulfur was fixed in the form of $\mathrm{ZnS}$, but the molten salt itself hardly participated in the smelting reaction and could be returned for recycling. A large amount of $\mathrm{Zn}$ oxide ash is produced in $\mathrm{Pb}-\mathrm{Zn}$ smeltery and steel plants. Although it is an important secondary resource, it is difficult to recover because of the presence of high amounts of $\mathrm{F}$ and $\mathrm{Cl}$. Thus, using this secondary $\mathrm{ZnO}$ ash as a sulfur-fixing agent is a comprehensive way to utilize resources and produce $\mathrm{ZnS}$, which can be returned to the $\mathrm{Zn}$ smelter. Our team investigated the molten salt smelting of stibnite in the laboratory, and the $\mathrm{Sb}$ generation rate and sulfur-fixing rate were both higher than $90 \%[22,23]$. This new method is a low-carbon and environmentally friendly process.

Generally, stibnite has a variety of associated sulfides and gangues, and the behaviors of these components were unclear in the smelting process. Thus, this study had the goal of understanding the behaviors of the associated minerals, including $\mathrm{PbS}, \mathrm{FeS}_{2}, \mathrm{SiO}_{2}$, and $\mathrm{CaCO}_{3}$, during the molten salt smelting of stibnite based on thermodynamic calculations and X-ray diffraction (XRD) and Thermogravimetric-differential scanning calorimetry (TG-DSC) detection. Finally, a kilogram-class pilot test was performed in a rotary furnace to further verify the feasibility of the process.

\section{Experimental}

\subsection{Materials}

In the experiments conducted during the reaction behavior research, all reagents, including $\mathrm{Na}_{2} \mathrm{CO}_{3}, \mathrm{NaCl}, \mathrm{PbS}, \mathrm{FeS}_{2}, \mathrm{SiO}_{2}, \mathrm{CaCO}_{3}$, and carbon powder, were of analytical grade, and all of them were dried in an oven at $60{ }^{\circ} \mathrm{C}$ for $24 \mathrm{~h}$. An $\mathrm{Na}_{2} \mathrm{CO}_{3}-\mathrm{NaCl}$ binary salt eutectic composition was used [22]. The Au-bearing Sb sulfide concentrate used in the kilogram-class pilot experiments was provided by Chenzhou Mining (Hunan, China). It contained $48.08 \% \mathrm{Sb}$ and $\mathrm{Au}$ at $101.05 \mathrm{~g} / \mathrm{t}$, and its chemical composition and XRD pattern are provided in Table 1 and Figure 1, respectively. It can be seen that the main phases are $\mathrm{Sb}_{2} \mathrm{~S}_{3}, \mathrm{FeS}_{2}$, and $\mathrm{SiO}_{2}$. Other auxiliary materials used in the pilot test 
included industrial-grade $\mathrm{Na}_{2} \mathrm{CO}_{3}, \mathrm{NaCl}$, and $\mathrm{ZnO}$. The main components of reductant coal are listed in Table 2.

Table 1. Chemical composition of central south stibnite concentrate.

\begin{tabular}{ccccccccccc}
\hline Elements & $\mathbf{S b}$ & $\mathbf{S}$ & $\mathbf{F e}$ & $\mathbf{P b}$ & $\mathbf{C u}$ & $\mathrm{As}$ & $\mathbf{B i}$ & $\mathbf{A u} /(\mathrm{g} / \mathbf{t})$ & $\mathrm{SiO}_{2}$ & $\mathbf{C a O}$ \\
\hline Content $(\mathrm{wt} \%)$ & 48.08 & 25.13 & 5.14 & 0.28 & 0.039 & 0.50 & 0.0037 & 101.05 & 12.14 & 0.90 \\
\hline
\end{tabular}

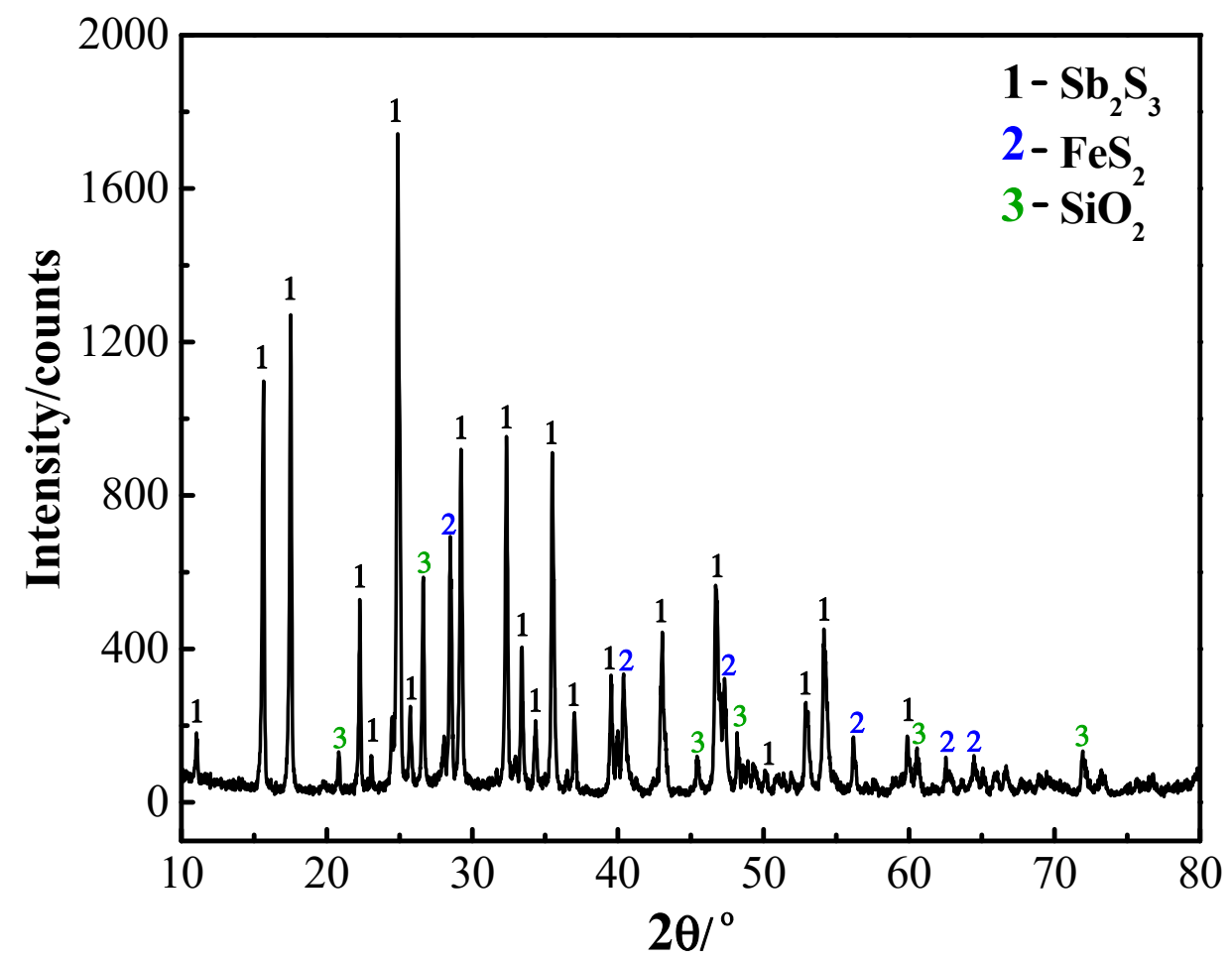

Figure 1. X-ray diffraction (XRD) pattern of stibnite concentrate.

Table 2. Chemical composition of reductant coal in pilot scale experiments.

\begin{tabular}{ccccc}
\hline Composition & C & Volatile & Ash & Other \\
\hline Content $(w t \%)$ & 70.00 & 12.00 & 10.00 & 8.00 \\
\hline
\end{tabular}

\subsection{Methods and Procedures}

\subsubsection{Laboratory Experiments}

The pure and single associated minerals in stibnite were used to reacted with $\mathrm{Na}_{2} \mathrm{CO}_{3}$ for reaction behaviors investigation in laboratory, and the sampled amounts were calculated using $n\left(\mathrm{Na}_{2} \mathrm{CO}_{3}\right)$ : $\mathrm{n}$ (associated minerals): $\mathrm{n}$ (carbon) $=1: 1: 1$, and every sample was subjected to TG-DSC analysis after mixing. The reaction temperature was deduced using the endothermic and exothermic peaks in the TG-DSC pattern. Then, $10 \mathrm{~g}$ of the mixture was charged in an alumina crucible at the reaction temperature for $2 \mathrm{~h}$. The products were prepared for XRD analyses. All of the experiments were performed using dehydrated high-purity argon gas. The TG-DSC analyses were conducted using a Universal V4.0C thermogravimetric analyzer (TA instrument, New Castle, DE, US) in a nitrogen flow of $100 \mathrm{~mL} / \mathrm{min}$ and at a heating rate of $10^{\circ} \mathrm{C} / \mathrm{min}$. X-ray diffraction (XRD) studies were performed using a D/max $2550 \mathrm{VB}+18 \mathrm{~kW}$ powder diffractometer (Rigaku, Akishima-Shi Tokyo, Japan) with a $\mathrm{Cu} / \mathrm{K} \alpha \mathrm{X}$-ray source at $40 \mathrm{kV}$ and $300 \mathrm{~mA}$. 


\subsubsection{Kilogram-ClassPilot Tests}

The rotary furnace with the flue gas treatment device used for the kilogram-class pilot tests is shown in Figure 2. In every test, $50 \mathrm{~kg}$ of stibnite was used based on the test scale. The external size of the rotary kiln was $\varnothing 1620 \times 1910 \mathrm{~mm}^{2}$, and it adopted a diesel burner to provide heat. The $\mathrm{Sb}_{2} \mathrm{~S}_{3}$ concentrate, $\mathrm{ZnO}$, $\mathrm{Na}_{2} \mathrm{CO}_{3}, \mathrm{NaCl}$, and coal particles were weighed according to the calculated proportions and mixed well. A feeding hopper was used for mixture material addition on the left side of a short kiln. The induced draft fan was turned on when the diesel burner was ignited and was continued to run throughout the smelting process. The furnace was heated by burning diesel fuel and blowing air, and the temperature of the furnace hearth was detected using a thermocouple embedded in the refractory brick and a temperature-measuring gun. During the smelting process, the furnace was rotated several times in a small range every $30 \mathrm{~min}$ to increase the material contact. When the smelting concluded after reaching a predetermined time and temperature, the melt was removed using a downspout, leading to a slag charter, and was naturally cooled to indoor temperature. Then, the molten salt and Sb bullion (gathered Au) were separated by hand, and both were sampled and analyzed after grinding with a ball mill and water dissolution. The flue gas discharged from the furnace was cooled using water circulation and a cooling tower, and dust was gathered in a cyclone dust collector, purified by alkali liquor adsorption ( $3 \mathrm{wt} \% \mathrm{NaOH}$ solution), and was then discharged by the induced draft fan.

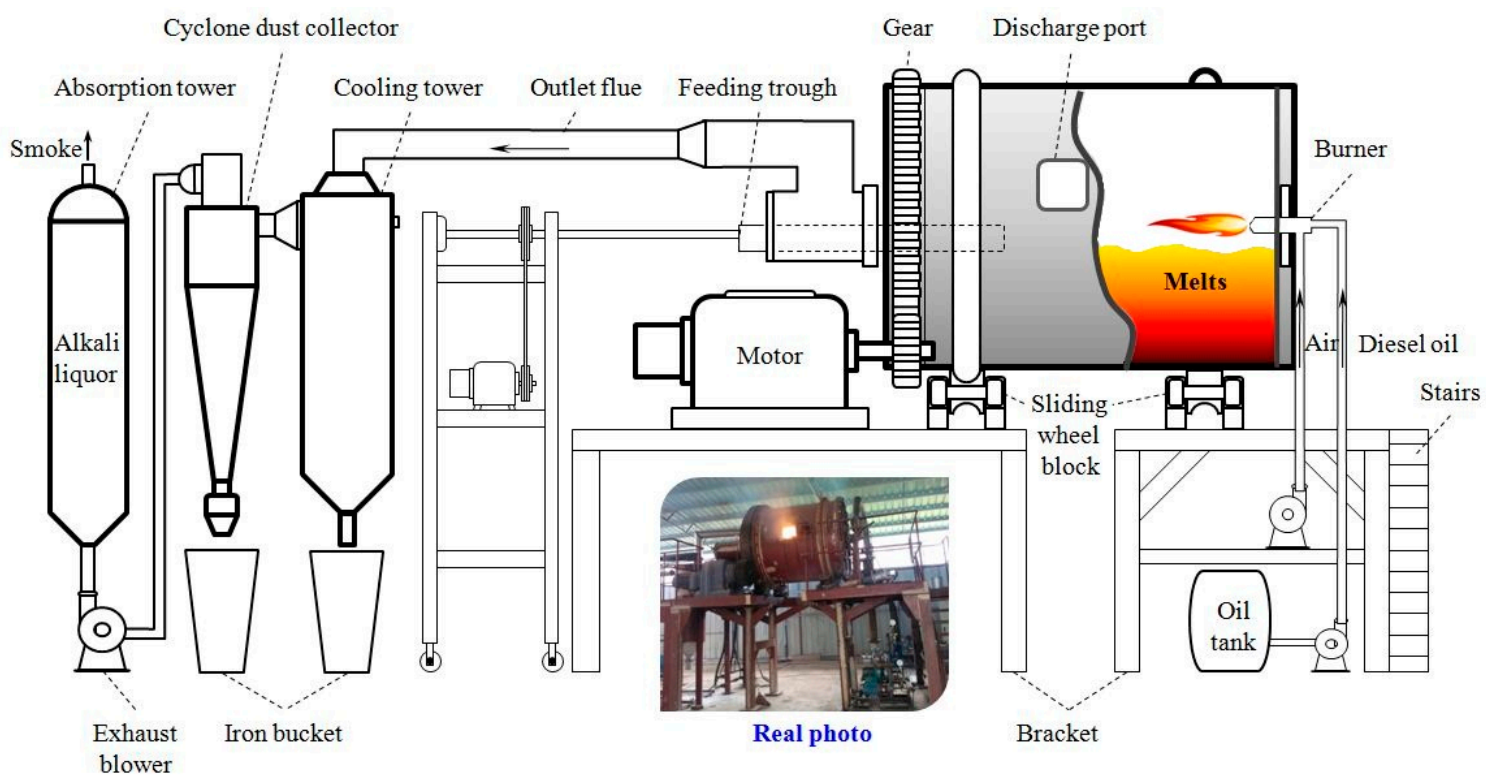

Figure 2. Rotary kiln and accessories for kilogram-class pilot experiments.

Atomic Absorption Spectroscopy (TAS-990, Purkinje General Instrument Co., Ltd. Beijing, China) was used for the analysis of the $\mathrm{Sb}$ in the slag, and the $\mathrm{Sb}$ content in the crude $\mathrm{Sb}$ was determined by titrimetric analysis (which used ceric sulfate to oxidize $\mathrm{Sb}(\mathrm{III})$ in to $\mathrm{Sb}(\mathrm{V})$ and excess ceric sulfate faded the color of the methyl orange solution). The Au contents in the Sb bullion and slag were detected by fire assaying. A sulfur analysis was performed using an infrared carbon-sulfur analyzer (CS444, LECO Co., LTD, San Jose, MI, US). The direct recovery rates (DRRs) for the Sb and Au, sulfur-fixing rate (SFR), and volatilization rate (VR) of $\mathrm{Sb}$ to smoke were calculated using the following equations, while the DRR of Au was calculated using the same method used for Sb.

$$
\begin{gathered}
\text { DRR of } \mathrm{Sb}=\frac{W_{2} \cdot x_{2} \%}{W_{1} \cdot x_{1} \%} \times 100 \% \\
\mathrm{SFR}=\frac{W_{3} \cdot c_{2}}{W_{1} \cdot c_{1}} \times 100 \%
\end{gathered}
$$




$$
\text { VR of } \mathrm{Sb}=\frac{W_{4} \cdot x_{3} \%}{W_{1} \cdot x_{1} \%} \times 100 \%
$$

where $W_{1}$ is the initial mass of stibnite (g); $W_{2}$ is the mass of the crude $\mathrm{Sb}(\mathrm{g}) ; W_{3}$ is the mass of the smelting salt (g); $W_{4}$ is the mass of the dust from smoke collection $(\mathrm{g}) ; x_{1}, x_{2}$, and $x_{3}$ are the Sb contents in the raw ore, crude $\mathrm{Sb}$, and dust (\%), respectively; and $c_{1}$ and $c_{2}$ are the sulfur contents in the initial stibnite and smelting salt $(\%)$, respectively.

\section{Results and Discussion}

\subsection{Thermogravimetric Analysis}

Figure 3 shows the TG-DSC results for the different associated minerals and molten salts with carbon addition. Figure 3 a shows the reaction results of $\mathrm{PbS}$, where the molar ratio is $n(\mathrm{PbS}): \mathrm{n}\left(\mathrm{Na}_{2} \mathrm{CO}_{3}\right)$ : $\mathrm{n}(\mathrm{C})=1: 1: 2$. It can be seen from Figure 3 a that there is an apparent endothermic peak at $626.78{ }^{\circ} \mathrm{C}$, where the sharp peak indicates that a strong endothermic reaction occurred with a remarkable mass loss in the system. The eutectic point of $\mathrm{Na}_{2} \mathrm{CO}_{3}-\mathrm{NaCl}$ is $635^{\circ} \mathrm{C}$ [24-26]. Thus, the endothermic peak at $626.78{ }^{\circ} \mathrm{C}$ was attributed to the melting of the mixture, and reaction accelerated because of the liquid-solid reaction after melting. The second exothermic peak emerged at $800{ }^{\circ} \mathrm{C}$. This peak was small and gentle, but the mass loss was further accelerated after $800^{\circ} \mathrm{C}$, which may have been caused by gas emission and flux volatilization. It is noteworthy that $\mathrm{Na}_{2} \mathrm{CO}_{3}$ does not decompose before $900{ }^{\circ} \mathrm{C}[27,28]$. Finally, two endothermic peaks appeared around $850^{\circ} \mathrm{C}$, and the mass loss was significant. Based on thermal stability research [29], these can be attributed to the volatilization of the salt.
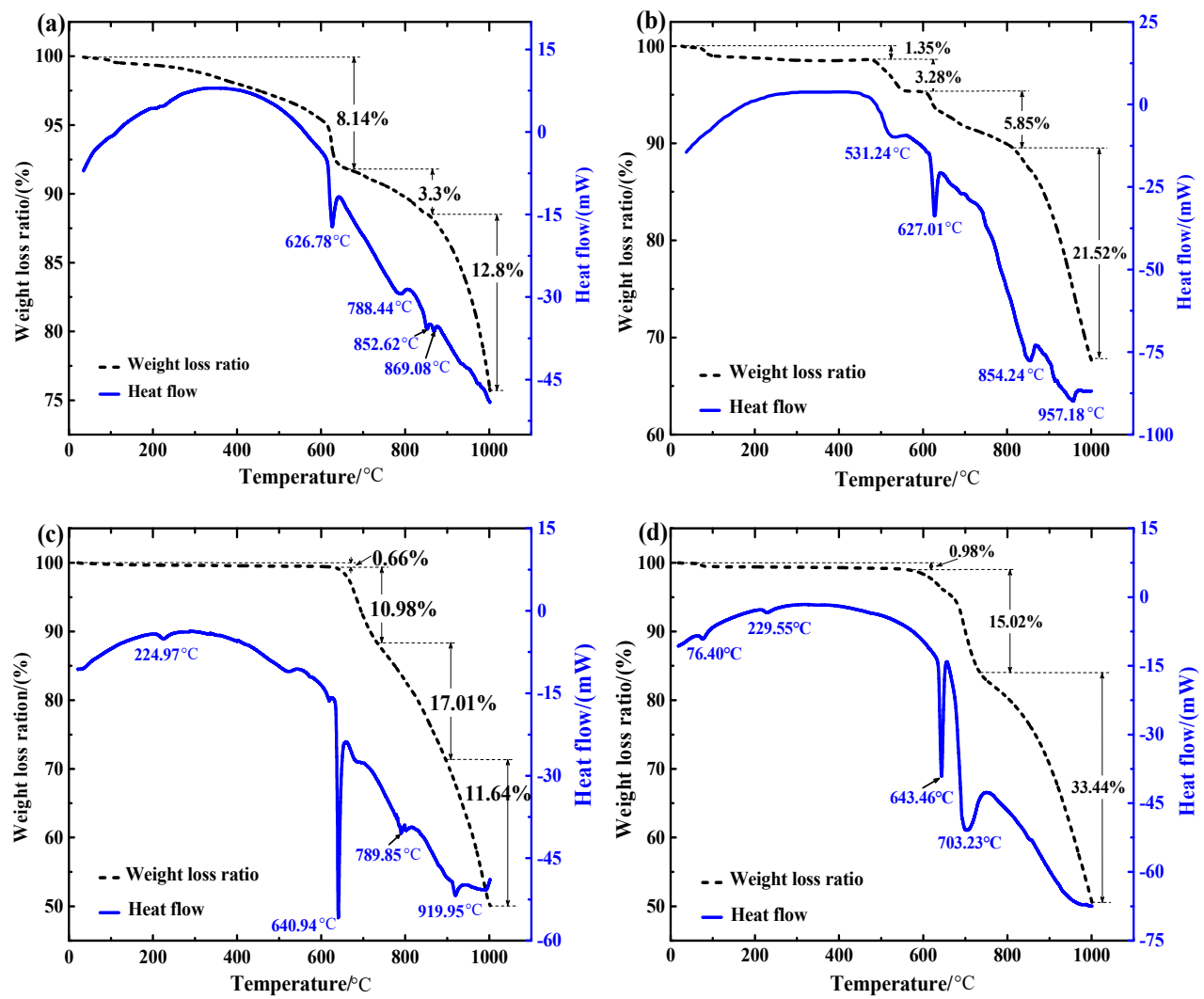

Figure 3. Thermogravimetric-differential scanning calorimetry (TG-DSC) diagrams of different impurities and molten salts (a) $\mathrm{PbS}$ with carbon addition, (b) $\mathrm{FeS}_{2}$ with carbon addition, (c) $\mathrm{SiO}_{2}$ without carbon addition, (d) $\mathrm{CaCO}_{3}$ without carbon addition).

The results of the TG-DSC analysis of $\mathrm{FeS}_{2}$ and eutectic salt are shown in Figure $3 \mathrm{~b}$. The experimental materials were prepared with a molar ratio of 1:2:4 $\left(n\left(\mathrm{FeS}_{2}\right): \mathrm{n}\left(\mathrm{Na}_{2} \mathrm{CO}_{3}\right): \mathrm{n}(\mathrm{C})\right)$. 
The weight loss curve can be divided into four sections: a loss of approximately $1.35 \%$ before $470{ }^{\circ} \mathrm{C}$, $3.28 \%$ at $470-600{ }^{\circ} \mathrm{C}, 5.58 \%$ at $600-800{ }^{\circ} \mathrm{C}$, and $21.52 \%$ at $800-1000{ }^{\circ} \mathrm{C}$. In addition, four endothermic peaks at $531.24{ }^{\circ} \mathrm{C}, 627.01{ }^{\circ} \mathrm{C}, 854.24{ }^{\circ} \mathrm{C}$, and $957.18{ }^{\circ} \mathrm{C}$ were observed on the heat flow curve. The first peak and mass loss were caused by dehydration. The second peak, like the one in Figure $3 \mathrm{a}$, was attributed to the melting of the mixture. The last two peaks were relatively gentle and may have been caused by decomposition and interactive reactions.

The TG-DSC results for the $\mathrm{SiO}_{2}$ in the $\mathrm{NaCl}-\mathrm{Na}_{2} \mathrm{CO}_{3}$ molten salt are shown in Figure 3c. The materials used in the test were prepared according to the mole ratio of $\mathrm{n}\left(\mathrm{SiO}_{2}\right): \mathrm{n}\left(\mathrm{Na}_{2} \mathrm{CO}_{3}\right)=1: 1$, without a carbon addition. There were four endothermic peaks, and the first peak was the dehydration peak at $224.97^{\circ} \mathrm{C}$. The process had a low weightlessness rate of $0.66 \%$. The second peak was still a result of the endothermic melting of the molten salt, at $640.94{ }^{\circ} \mathrm{C}$. The mass loss of the mixture began to accelerate during this process. The third endothermic peak appeared at $789.85^{\circ} \mathrm{C}$, and the peak strength was small, which may have been due to the chemical reaction in the mixture. At the same time, the system mass loss was accelerated. The last weak endothermic peak occurred at $919.95{ }^{\circ} \mathrm{C}$.

In the $\mathrm{CaCO}_{3}$ system, the TG-DSC analysis was also performed at a molar ratio of $(\mathrm{n}(\mathrm{CaCO})$ : $\mathrm{n}\left(\mathrm{Na}_{2} \mathrm{CO}_{3}\right)=1: 1$. It can be seen from the results that there were two smaller endothermic peaks in the low-temperature stage, at $76.40^{\circ} \mathrm{C}$ and $229.55^{\circ} \mathrm{C}$, and the quality was reduced by $0.98 \%$. These were the dehydration peaks of the materials. Then, there was a sharp endothermic peak and gentle endothermic peak, at $643.46{ }^{\circ} \mathrm{C}$ and $703.23^{\circ} \mathrm{C}$, respectively. The third sharp endothermic peak was also a result of the endothermic reaction of the molten salt melting. The fourth peak reaction was relatively gentle, but the mass loss of the system was accelerated. It may have been a result of the decomposition reaction of the $\mathrm{CaCO}_{3}$.

\subsection{Thermodynamic Analysis}

Based on the previously presented analysis of the thermal reaction behaviors, the possible reactions in different systems and their Gibbs free energy change $\left(\Delta \mathrm{G}^{\theta} \mathrm{T}\right)$ values are listed in Table 3. The $\Delta \mathrm{G}^{\theta}-\mathrm{T}$ relationships of these reactions were calculated and are shown in Figure 4, all the data included heat capacity $\left(c_{\mathrm{p}}\right)$, standard entropy change $\left(\Delta \mathrm{S}^{\theta_{\mathrm{T}}}\right)$ and enthalpy change $\left(\Delta \mathrm{H}^{\theta_{\mathrm{T}}}\right)$ were from the thermodynamic handbook [30]. As can be seen from Figure 4, for PbS, reactions (4)-(7) were all difficult below $800{ }^{\circ} \mathrm{C}$ because the $\Delta \mathrm{G}^{\theta}{ }_{\mathrm{T}}$ values were greater than zero. But the $\Delta \mathrm{G}^{\theta}{ }_{\mathrm{T}}$ values of reactions (4) and (7) became negative after $800{ }^{\circ} \mathrm{C}$. These were the main reactions of the alkali smelting and reaction smelting of the $\mathrm{PbS}$ ore, but the generation of $\mathrm{PbSO}_{4}$ was difficult. The $\mathrm{FeS}_{2}$, which is called pyrite in minerals, was easily decomposed and generated FeS during the smelting of stibnite. The $\Delta \mathrm{G}^{\theta} \mathrm{T}$ value of reaction (9) also showed that FeS was stable in the molten salt because it could not react with $\mathrm{Na}_{2} \mathrm{CO}_{3}$ below $1000{ }^{\circ} \mathrm{C}$. The $\mathrm{SiO}_{2}$, acidic oxide, could easily react with $\mathrm{Na}_{2} \mathrm{CO}_{3}$ from $300{ }^{\circ} \mathrm{C}$, because its $\Delta \mathrm{G}^{\theta} \mathrm{T}$ value became negative. The reaction released $\mathrm{CO}_{2}$ at the same time. Therefore, as shown in Figure $3 \mathrm{c}$, the mass loss of this reaction was larger than those of $\mathrm{FeS}_{2}$ and $\mathrm{PbS}$ in front. The $\Delta \mathrm{G}^{\theta} \mathrm{T}$ values of reaction (11) were less than zero after $870{ }^{\circ} \mathrm{C}$. As is well known, lime begins to decompose and its mass begins to decrease at approximately $1000{ }^{\circ} \mathrm{C}$, which is the temperature that lime is burned in industrial production. However, it is still unclear what reactions occurred between the $\mathrm{CaCO}_{3}, \mathrm{CaO}$, and molten salt.

Table 3. Possible reactions and their $\Delta \mathrm{G}^{\theta} \mathrm{T}$ values.

\begin{tabular}{lc}
\hline \multicolumn{1}{c}{ Reaction } & Number \\
\hline $2 \mathrm{PbS}+2 \mathrm{Na}_{2} \mathrm{CO}_{3}+\mathrm{C}=2 \mathrm{~Pb}+2 \mathrm{Na}_{2} \mathrm{~S}+3 \mathrm{CO}_{2}(\mathrm{~g})$ & $(4)$ \\
$4 \mathrm{PbS}+4 \mathrm{Na}_{2} \mathrm{CO}_{3}=4 \mathrm{~Pb}+3 \mathrm{Na}_{2} \mathrm{~S}+\mathrm{Na}_{2} \mathrm{SO}_{4}+4 \mathrm{CO}_{2}(\mathrm{~g})$ & $(5)$ \\
$\mathrm{PbS}+\mathrm{Na}_{2} \mathrm{SO}_{4}=\mathrm{PbSO}_{4}+\mathrm{Na}_{2} \mathrm{~S}$ & $(6)$ \\
$\mathrm{PbSO}_{4}+\mathrm{PbS}=2 \mathrm{~Pb}+2 \mathrm{SO}_{2}(\mathrm{~g})$ & $(7)$ \\
$2 \mathrm{FeS}_{2}=2 \mathrm{FeS}+\mathrm{S}_{2}(\mathrm{~g})$ & $(8)$ \\
$2 \mathrm{FeS}+2 \mathrm{Na}_{2} \mathrm{CO}_{3}+\mathrm{C}=2 \mathrm{Na}_{2} \mathrm{~S}+2 \mathrm{Fe}+3 \mathrm{CO}_{2}(\mathrm{~g})$ & $(9)$ \\
$\mathrm{SiO}_{2}+\mathrm{Na}_{2} \mathrm{CO}_{3}=\mathrm{Na}_{2} \mathrm{SiO}_{3}+\mathrm{CO}_{2}(\mathrm{~g})$ & $(10)$ \\
$\mathrm{CaCO}_{3}=\mathrm{CaO}+\mathrm{CO}_{2}(\mathrm{~g})$ & $(11)$ \\
\hline
\end{tabular}




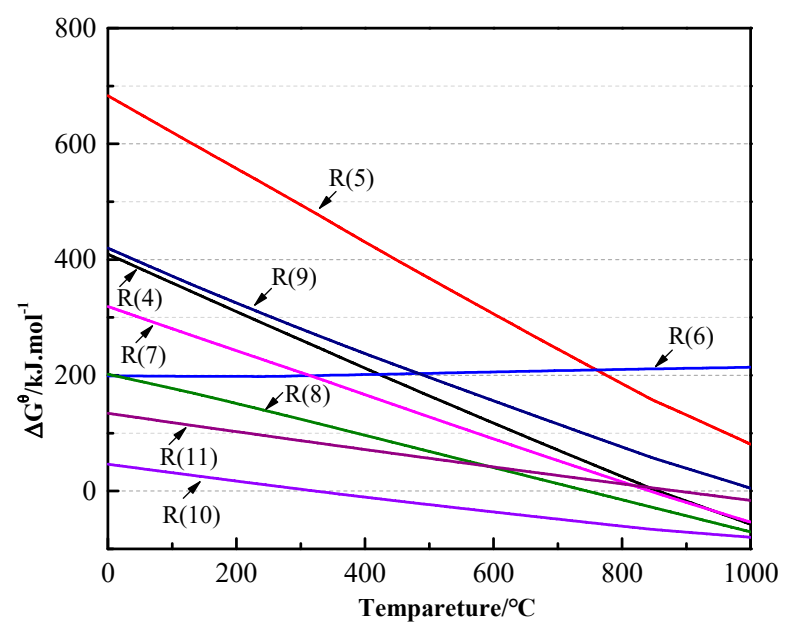

Figure 4. $\Delta \mathrm{G}_{\mathrm{T}}{ }^{\theta}$-T graph of reactions (4)-(11).

\subsection{Process Analysis}

To explore the reaction behaviors of the different associated minerals in molten salts, the reaction products of four systems at different temperatures were analyzed using XRD, using the same mole ratio as in the TG-DSC detection. The results are shown in Figure 5. In the PbS-molten salt-C system, four reaction temperatures were selected from the thermogravimetric curve. The results showed that metallic $\mathrm{Pb}$ was obtained after $700{ }^{\circ} \mathrm{C}$, with $\mathrm{Pb}$ mass values of $3.02,8.34$, and $9.15 \mathrm{~g}$ at $700{ }^{\circ} \mathrm{C}$, $850{ }^{\circ} \mathrm{C}$, and $950{ }^{\circ} \mathrm{C}$, respectively, which indicated $\mathrm{Pb}$ production rates of $31.85 \%, 88.04 \%$, and $96.55 \%$, respectively. According to the $\Delta \mathrm{G}^{\theta}{ }_{\mathrm{T}}$ calculations for reactions (4) and (7), metallic $\mathrm{Pb}$ can be generated by alkali and reaction smelting. An XRD analysis of the smelting salts was performed after the separation of the $\mathrm{Pb}$ bullion, and the results are shown in Figure 5a. It can be seen from the XRD results that the main components of the salts were $\mathrm{PbS}, \mathrm{NaCl}$, and $\mathrm{Na}_{2} \mathrm{CO}_{3}$ at $500{ }^{\circ} \mathrm{C}$. Thus, no reaction occurred in the mixture at this temperature. When the temperature exceeded $700{ }^{\circ} \mathrm{C}$ and continued to increase, the main component was changed to $\mathrm{Na}_{6}\left(\mathrm{SO}_{4}\right)_{2} \mathrm{CO}_{3}$, which is a compound of $\mathrm{Na}_{2} \mathrm{SO}_{4}$ and $\mathrm{Na}_{2} \mathrm{CO}_{3}$. This indicated that $\mathrm{Na}_{2} \mathrm{SO}_{4}$ was formed, possibly because part of the $\mathrm{PbS}$ reacted with $\mathrm{Na}_{2} \mathrm{CO}_{3}$ accorded by reaction (2). The amount of $\mathrm{NaCl}$ was basically unchanged.

For $\mathrm{FeS}_{2}$, considering the mass loss and thermal effect, six temperatures were selected for reaction behavior experiments. The XRD results of the products are shown in Figure $5 \mathrm{~b}$. It can be seen that no chemical reaction occurred at $400{ }^{\circ} \mathrm{C}$, and the product composition was still $\mathrm{FeS}_{2}$ and molten salt. When the temperature was increased to $600^{\circ} \mathrm{C}$, a large amount of $\mathrm{NaFeS}_{2}$ appeared in the product, which is also a compound of $\mathrm{Na}_{2} \mathrm{~S}$ and FeS. This should have been caused by the decomposition of $\mathrm{FeS}_{2}$ to form $\mathrm{FeS}$ and $\mathrm{S}_{2}$, after which the $\mathrm{S}_{2}$ was absorbed to form $\mathrm{Na}_{2} \mathrm{~S}$, and the $\mathrm{Na}_{2} \mathrm{~S}$ and $\mathrm{FeS}$ were easily combined to form $\mathrm{NaFeS}_{2}$. Until the temperature reached $970{ }^{\circ} \mathrm{C}$, the composition of the product was $\mathrm{NaFeS}_{2}$ and $\mathrm{NaCl}$, which could exist stably in the system.

The reactions between $\mathrm{SiO}_{2}$ and binary salt were investigated at four temperatures. It can be seen from Figure $5 \mathrm{c}$ that there was no reaction in the mixture below $700^{\circ} \mathrm{C}$. When the temperature exceeded $700{ }^{\circ} \mathrm{C}, \mathrm{SiO}_{2}$ and $\mathrm{Na}_{2} \mathrm{CO}_{3}$ reacted to form $\mathrm{Na}_{2} \mathrm{SiO}_{3}$ following reaction (10), which corresponded to the absorption peak at $789.85^{\circ} \mathrm{C}$ in the TG-DSC curves, along with $\mathrm{NaCl} . \mathrm{Na}_{2} \mathrm{SiO}_{3}$ was stable in the salt until the temperature increased to $950{ }^{\circ} \mathrm{C}$. For $\mathrm{CaCO}_{3}$, reactions were performed at three temperatures. It can be seen from the phase analysis results that the product was a mixture of $\mathrm{CaCO}_{3}, \mathrm{NaCl}$, and $\mathrm{Na}_{2} \mathrm{CO}_{3}$, and no reaction occurred at $500^{\circ} \mathrm{C}$. When the temperature reached $675{ }^{\circ} \mathrm{C}$, the compound of $\mathrm{CaCO}_{3}$ and $\mathrm{Na}_{2} \mathrm{CO}_{3}$ appeared in the product. This showed that the $\mathrm{Na}_{2} \mathrm{CO}_{3}$ peaks appeared at $800{ }^{\circ} \mathrm{C}$, which might indicate that $\mathrm{Na}_{2} \mathrm{Ca}\left(\mathrm{CO}_{3}\right)_{2}$ was partially decomposed. Thus, $\mathrm{CaCO}_{3}$ did not decompose but remained stable in the molten salt. 

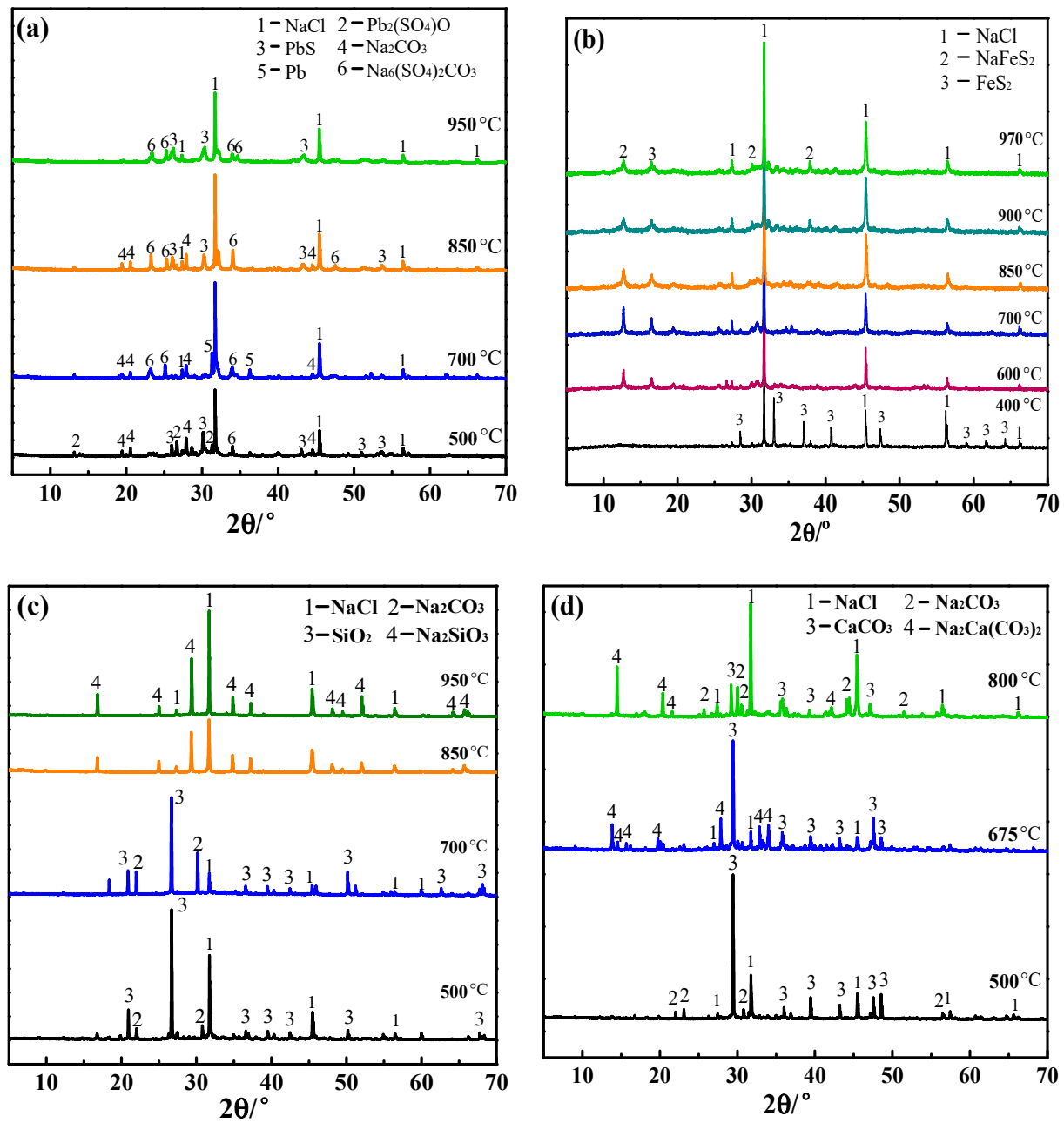

Figure 5. XRD diagrams of products baked with different impurities and molten salts at different temperatures (a) $\mathrm{PbS}$ with carbon addition, (b) $\mathrm{FeS}_{2}$ with carbon addition, (c) $\mathrm{SiO}_{2}$ without carbon addition, (d) $\mathrm{CaCO}_{3}$ without carbon addition.

\subsection{Kilogram-Class Pilot Tests}

In order to verify the feasibility of the molten salt smelting of stibnite and further investigate the behaviors of the associated minerals during smelting, kilogram-class pilot tests were carried out in a rotary kiln. The conditions and results are listed in Table 4. It can be seen from No.1 to No.5 that the DRR values of both $\mathrm{Sb}$ and $\mathrm{Au}$ increased with the $\mathrm{NaCl}$ content. As shown in the phase diagram of $\mathrm{NaCl}-\mathrm{Na}_{2} \mathrm{CO}_{3}$, the eutectic composition of the system was at $43 \% \mathrm{NaCl}$ with a eutectic point of $636{ }^{\circ} \mathrm{C}$ [29]. The melting point of the mixture decreased with an increase in the $\mathrm{NaCl}$ content, and the mobility of flux also improved. Because the price of $\mathrm{NaCl}$ is lower than that of $\mathrm{Na}_{2} \mathrm{CO}_{3}$, the eutectic composition was adopted for smelting. An increasing the amount of $\mathrm{ZnO}$ will reduce the DRR because it has a high melting point and will increase the viscosity of the melt. It can be seen for No.6 to No.8 that the DRR improved with increases in the temperature and reaction time, but the DRR values of $\mathrm{Sb}$ and $\mathrm{Au}$ were still $80.03 \%$ and $85.17 \%$, respectively. Thus, for No.9-No.11, the amount of salt was increased to four or five times the ore mass, and the smelting results obviously increased. The DRR values of $\mathrm{Sb}$ and $\mathrm{Au}$ were both higher than $90 \%$ at $920^{\circ} \mathrm{C}$ for $8 \mathrm{~h}$ and $870{ }^{\circ} \mathrm{C}$ for $10 \mathrm{~h}$, and the lowest $\mathrm{Sb}$ content in the slag was $1.28 \%$. It can be seen from Table 4 that the sulfur-fixing rate was high in all the tests, and the highest sulfur-fixing rate reached $96.3 \%$. Even if the reaction was not carried out completely, the sulfur in the ore still existed in the form of sulfide. Thus, the apparent sulfur-fixing rate was high. During the volatilization of $\mathrm{Sb}$ and its compounds, which led to a certain volatilization and allowed them to enter the final smoke, but this smoke could return to ingredients. 
Table 4. Smelting results under different experimental conditions in kilogram-class pilot tests.

\begin{tabular}{|c|c|c|c|c|c|c|c|c|c|c|c|c|c|c|}
\hline \multirow{2}{*}{$\begin{array}{l}\text { Test } \\
\text { No. }\end{array}$} & \multicolumn{6}{|c|}{ Conditions } & \multicolumn{4}{|c|}{ Metal } & \multicolumn{3}{|c|}{ Molten Salt Slag } & \multirow{2}{*}{$\begin{array}{c}\text { Smoke } \\
\text { VR of } \mathrm{Sb} \\
(\%)\end{array}$} \\
\hline & $\begin{array}{l}\mathrm{Na}_{2} \mathrm{CO}_{3} \\
(\mathrm{~kg})\end{array}$ & $\begin{array}{c}\mathrm{NaCl} \\
(\mathrm{kg})\end{array}$ & $\begin{array}{c}\mathrm{ZnO} \\
\text { (times) }\end{array}$ & $\begin{array}{c}\text { Carbon } \\
(\mathrm{kg})\end{array}$ & $\begin{array}{c}\text { Temperature } \\
\left({ }^{\circ} \mathrm{C}\right)\end{array}$ & $\begin{array}{c}\text { Time } \\
\text { (h) }\end{array}$ & $\begin{array}{c}\mathrm{Sb} \\
\text { (pct) }\end{array}$ & $\begin{array}{c}\mathrm{Au} \\
(\mathrm{g} / \mathrm{t})\end{array}$ & $\begin{array}{c}\text { DRR of } \mathrm{Sb} \\
(\%)\end{array}$ & $\begin{array}{c}\text { DRR of Au } \\
(\%)\end{array}$ & $\begin{array}{c}\mathrm{Sb} \\
(\mathrm{pct})\end{array}$ & $\underset{(g / t)}{A u}$ & $\begin{array}{l}\text { SFR } \\
(\%)\end{array}$ & \\
\hline 1 & 145.00 & 5.00 & 1.00 & 7.50 & 920 & 5 & 89.00 & 143 & 10.23 & 7.83 & 11.48 & 24 & 81.03 & 3.83 \\
\hline 2 & 120.00 & 30.00 & 1.00 & 7.50 & 920 & 8 & 93.76 & 166 & 58.20 & 49.04 & 6.23 & 17 & 94.99 & 4.12 \\
\hline 3 & 85.50 & 64.50 & 1.00 & 7.50 & 920 & 8 & 94.24 & 202 & 76.54 & 78.16 & 3.40 & 7 & 96.20 & 4.03 \\
\hline 4 & 70.00 & 80.00 & 1.00 & 7.50 & 920 & 8 & 93.11 & 212 & 70.38 & 76.22 & 4.40 & 8 & 96.06 & 3.95 \\
\hline 5 & 85.50 & 64.50 & 1.20 & 7.50 & 920 & 8 & 84.36 & 195 & 68.27 & 75.19 & 4.19 & 8 & 98.75 & 4.69 \\
\hline 6 & 85.50 & 64.50 & 1.00 & 10.00 & 920 & 8 & 92.09 & 201 & 77.19 & 80.24 & 3.24 & 8 & 98.35 & 4.55 \\
\hline 7 & 85.50 & 64.50 & 1.00 & 10.00 & 970 & 8 & 94.14 & 207 & 79.44 & 83.15 & 2.69 & 6 & 97.28 & 5.18 \\
\hline 8 & 85.50 & 64.50 & 1.00 & 10.00 & 970 & 12 & 92.58 & 207 & 80.03 & 85.17 & 2.38 & 5 & 98.03 & 6.40 \\
\hline 9 & 114.00 & 86.00 & 1.00 & 10.00 & 970 & 8 & 95.13 & 205 & 87.06 & 89.30 & 1.24 & 4 & 98.72 & 4.76 \\
\hline 10 & 142.50 & 107.50 & 1.00 & 10.00 & 920 & 8 & 96.42 & 200 & 93.22 & 92.06 & 0.46 & 2 & 99.30 & 4.02 \\
\hline 11 & 142.50 & 107.50 & 1.00 & 10.00 & 870 & 10 & 95.58 & 202 & 92.37 & 92.77 & 0.48 & 2 & 99.49 & 2.65 \\
\hline
\end{tabular}


The delamination of the smelting products and XRD patterns of the molten salt slag from test No.11 before and after water dissolution are shown in Figure 6. It can be seen from Figure 6a that the slag and crude $\mathrm{Sb}$ after smelting have obvious stratification, with the crude Sb below the slag. Thus, it would be easy to directly siphon off the molten Sb during industrial production at a high temperature. The XRD results of the molten salt slag before water dissolution showed that the constituents included $\mathrm{NaCl}$, $\mathrm{Na}_{2} \mathrm{CO}_{3}, \mathrm{ZnS}, \mathrm{FeS}$, and $\mathrm{Na}_{2} \mathrm{ZnSiO}_{4}$. Thus, the main composition of the molten salt was not changed by smelting. The sulfur phase changed from $\mathrm{Sb}_{2} \mathrm{~S}_{3}$ and $\mathrm{FeS}_{2}$ to $\mathrm{ZnS}$ and FeS, respectively, indicating that the sulfur-fixing reaction was also sufficient.

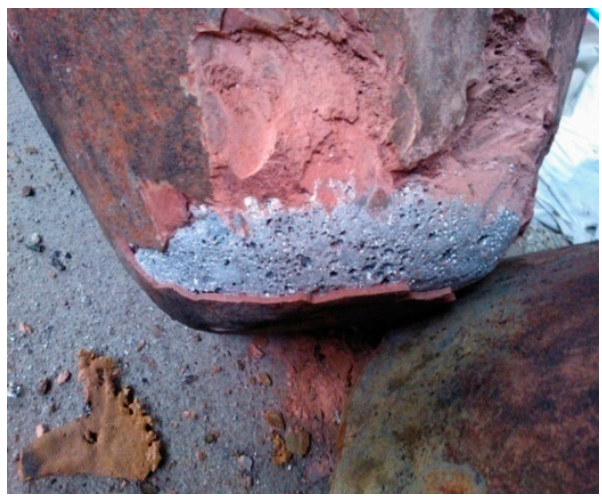

(a)

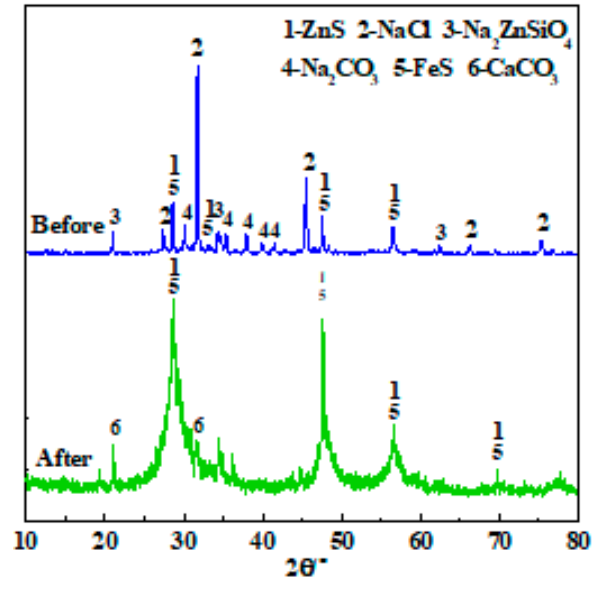

(b)

Figure 6. (a) Stratification of smelting products, and (b) XRD patterns of molten salt residue before and after water dissolution.

Because a large amount of molten salt was added and made the proportion of the reaction products of the associated minerals low, so their characteristic peaks might not be discerned by XRD. Therefore, the soluble $\mathrm{NaCl}$ and $\mathrm{Na}_{2} \mathrm{CO}_{3}$ in $1000.00 \mathrm{~g}$ of molten salt residue were washed away by hot water, and $228.57 \mathrm{~g}$ of insoluble residue and $4340.00 \mathrm{~mL}$ of lixivium were obtained. An XRD analysis of this insoluble residue was then conducted. The main components of the slag were $\mathrm{ZnS}, \mathrm{FeS}$, and $\mathrm{CaCO}_{3}$. Thus, $\mathrm{CaCO}_{3}$ minerals were stable which was consistent with the previously mentioned issues met the front issues. No other phases were detected because of their low content. Therefore, a detailed element balance was conducted based on the quantitative analysis.

The mass of crude Sb obtained from test 11 was $23.23 \mathrm{~kg}$, and the element constituents of this crude Sb, insoluble residue, and lixivium were analyzed, with the results listed in Table 5. The element content of the insoluble residue and lixivium actually represented the soluble and insoluble proportions of the molten salt residue. As can be seen from Table 5, in addition to $\mathrm{Sb}$ and $\mathrm{Au}, 18.80 \%$ and $7.43 \%$ of the total Fe and As were gathered in the crude $\mathrm{Sb}$. Thus, a portion of the FeS was reduced to metallic Fe. The main components of the insoluble residue were $\mathrm{Zn}, \mathrm{S}$, and Fe, which accounted for 38.01\%, $25.44 \%$, and $13.14 \%$, respectively. This verified the results of the XRD analysis that the main phases of the residue were FeS and $\mathrm{ZnS}$. The $\mathrm{S}$ content in the lixivium reached $1338 \mathrm{mg} / \mathrm{L}$. Therefore, in addition to the soluble sodium salt, soluble sulfur compounds like $\mathrm{Na}_{2} \mathrm{SO}_{4}$ and $\mathrm{Na}_{2} \mathrm{~S}$ were also generated, and the total sulfur-fixing rate was high. There was also a portion of soluble silicon in the solution for the formation of $\mathrm{Na}_{2} \mathrm{SiO}_{3}$.

According to the element analysis results, the distribution of elements in the crude $\mathrm{Sb}$ and molten salt slag could be divided into soluble and insoluble parts based on the proportions of insoluble residue and lixivium, which were calculated and are shown in Figure 7. It can be seen that the Sb, $\mathrm{Au}$, and $\mathrm{As}$ elements were the main enrichments in the crude metal, and accounted for $92.37 \%, 92.77 \%$, and $86.98 \%$ of the total quantity of the added ore, respectively. Because of the strong ability of Sb to collect Au, most of the Au was enriched by crude $\mathrm{Sb}$, which facilitated the recovery of $\mathrm{Au}$ in the subsequent 
refining process. Arsenic has properties similar to $\mathrm{Sb}$ in nature. Thus, arsenic had the same behavior as $\mathrm{Sb}$ and was reduced to a simple substance and gathered in the crude $\mathrm{Sb}$ in a reducing atmosphere. In addition, $18.80 \%$ Fe and $1.05 \% \mathrm{Zn}$ were gathered in the crude $\mathrm{Sb}$. Fe could be generated by reaction (9), and its $\Delta \mathrm{G}^{\theta}$ value was negative above $1000^{\circ} \mathrm{C}$. The practice of $\mathrm{Zn}$ smelting shows that $\mathrm{Zn}$ oxide is difficult to reduce below $1000^{\circ} \mathrm{C}$. Thus, $\mathrm{ZnO}$ could be used as a stable sulfur-fixing agent. On the other hand, $\mathrm{Fe}, \mathrm{Zn}$, and $\mathrm{S}$ were mainly concentrated in the molten salt residue and insoluble. Based on the XRD results in Figure $6 \mathrm{~b}$, sulfur was fixed in the form of stable $\mathrm{ZnS}$ and FeS in the smelting process, accounting for $96.31 \%$ and $81.20 \%$, respectively. However, possibly as a result of the insufficient contact between the materials, some sulfur reacted with alkali to form a soluble salt, accounting for $12.89 \%$, and was not fixed by $\mathrm{Zn}$ oxide. Nevertheless, the total sulfur fixation rate (sulfur in the molten salt slag) reached $99.49 \%$. The behaviors of $\mathrm{Ca}$ and $\mathrm{Si}$ were consistent with the previous analysis results, with $98.76 \%$ of the $\mathrm{Ca}$ and $81.15 \%$ of the $\mathrm{Si}$ insoluble in the water dissolution residue. The remainder of the $\mathrm{Si}$ might yield soluble silicateby $\mathrm{SiO}_{2}$ and $\mathrm{Na}_{2} \mathrm{CO}_{3}$ according to reaction (10).

Table 5. Mass of product and its chemical composition obtained from test 11.

\begin{tabular}{ccccccccccc}
\hline \multirow{2}{*}{ Product } & \multicolumn{10}{c}{ Composition (Solid: \%; Solution: $\mathbf{m g} / \mathbf{L}$ ) } \\
\cline { 2 - 11 } & $\mathbf{S b}$ & Fe & $\mathbf{S}$ & Zn & As & Au & Na & Si & Ca & Al \\
\hline Crude $\mathrm{Sb}$ & 95.58 & 2.08 & 0.05 & 0.95 & 0.89 & 202 & - & - & - & - \\
Residue & 2.34 & 13.14 & 25.44 & 38.01 & 0.003 & 6 & 3.17 & 6.19 & 0.14 & 2.17 \\
Lixivium & 48.89 & - & 1338.00 & 106.00 & 2.50 & - & $>3000$ & 613.00 & - & 21.39 \\
Dust & 33.52 & 0.75 & 3.15 & 6.88 & 0.13 & - & 20.47 & 1.20 & 1.06 & 0.79 \\
\hline \multicolumn{18}{c}{ Tip: The unit for Au is $\mathrm{g} / \mathrm{t}}$.
\end{tabular}

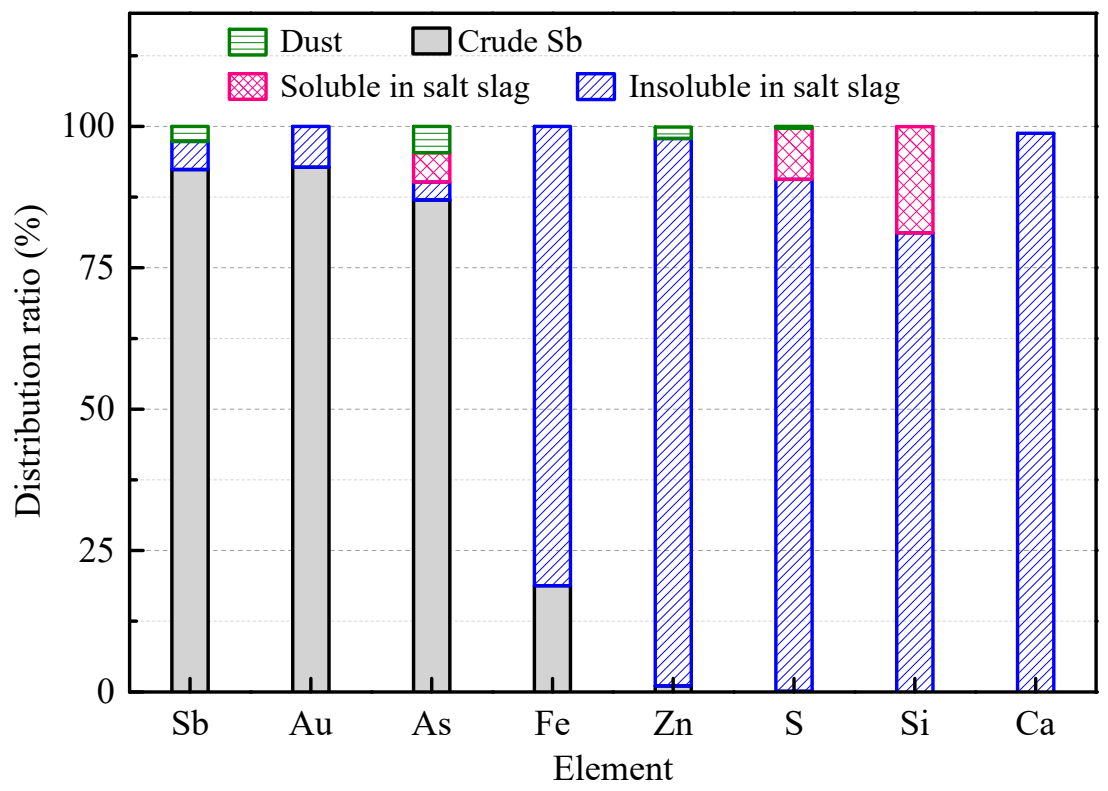

Figure 7. Element distribution in crude Sb, molten salt slag, and smoke.

\section{Conclusions}

The reaction behaviors of the associated minerals in stibnite with the $\mathrm{Na}_{2} \mathrm{CO}_{3}-\mathrm{NaCl}$ binary salt were analyzed, and kilogram-class trials of the molten salt smelting of stibnite were conducted. The results showed that $\mathrm{PbS}$ could easily participate in reduction reactions with $\mathrm{Na}_{2} \mathrm{CO}_{3}$, and carbon and metallic $\mathrm{Pb}$ were obtained after $700{ }^{\circ} \mathrm{C}$, with the production rate of $\mathrm{Pb}$ reaching $96.55 \%$ at $950{ }^{\circ} \mathrm{C}$. $\mathrm{FeS}_{2}$ formed stable $\mathrm{NaFeS}_{2}$ with the molten salt at a high temperature. $\mathrm{SiO}_{2}$ was converted to $\mathrm{Na}_{2} \mathrm{SiO}_{3}$ after $850{ }^{\circ} \mathrm{C}$, and $\mathrm{CaCO}_{3}$ form the unstable compound $\mathrm{Na}_{2} \mathrm{Ca}\left(\mathrm{CO}_{3}\right)_{2}$ with the molten salt, which consumed a portion of the molten salt. The results of a pilot test with a scale of $50 \mathrm{~kg}$ of concentrate 
showed that the direct recovery rate of $\mathrm{Sb}$ and $\mathrm{Au}$ reached $92.37 \%$ and $92.77 \%$ under the optimum conditions of temperature $920^{\circ} \mathrm{C}$, reaction time $8 \mathrm{~h}, 1.0$ stoichiometric amount of $\mathrm{ZnO}$ and eutectic $\mathrm{Na}_{2} \mathrm{CO}_{3}-\mathrm{NaCl}$ molten salt, and $\mathrm{Sb}$ bullion was obviously stratified with the molten salt slag after smelting. The element distribution also verified the results of the reaction behavior research, which showed that $\mathrm{Sb}$ and $\mathrm{Au}$ were mainly distributed in crude $\mathrm{Sb}$, and $\mathrm{Fe}, \mathrm{Zn}, \mathrm{S}, \mathrm{Si}$, and Ca were mainly enriched in the molten salt slag and insoluble. Sulfur was fixed in the form of $\mathrm{ZnS}$ and FeS, and a total sulfur-fixing rate of $99.49 \%$ was achieved.

Author Contributions: Z.O. and Y.X. carried out the experiments research and L.Y. designed the research and wrote the paper, C.T. reviewed and contributed to the final manuscript. All authors have read and agreed to the published version of the manuscript.

Funding: This research was funded by National Nature Science Foundation of China, grant number 51604105.

Acknowledgments: This project was supported financially by the National Nature Science Foundation of China (Grant No. 51604105), for which the authors are grateful.

Conflicts of Interest: The authors declare no conflict of interest.

\section{References}

1. Gierlotka, W. Thermodynamic description of the binary Au-Sb and ternary Au-In-Sb systems. J. Alloys Compd. 2013, 579, 533-539. [CrossRef]

2. Anderson, C.G. The metallurgy of antimony. Chem. Erde-Geochem. 2012, 72, 3-8. [CrossRef]

3. Yang, J.G.; Tang, C.B.; Chen, Y.M.; Tang, M.T. Separation of antimony from a stibnite concentrate through a low-temperature smelting process to eliminate $\mathrm{SO}_{2}$ emission. Metall. Mater. Trans. B 2011, 42, 30-36. [CrossRef]

4. Habashi, F. Handbook of Extractive Metallurgy, Volume II, 1st ed.; WILEY-VCH: Weinheim, Germany, 1997.

5. Awe, S.A.; Sundkvist, J.E.; Bolin, N.J.; Sandstrom, A. Process flowsheet development for recovering antimony from Sb-bearing copper concentrates. Miner. Eng. 2013, 49, 45-53. [CrossRef]

6. Awe, S.A.; Sandstrom, A. Selective leaching of arsenic and antimony from a tetrahedrite rich complex sulphide concentrate using alkaline sulphide solution. Miner. Eng. 2010, 23, 1227-1236. [CrossRef]

7. Lie, X.Q.; Zhong, Q.Y.; Lin, S.Y.; Chu, S.Z. Antimony white production from antimony sulfide ore using acidic solution of antimony pentachloride as lixiviant. J. Cent. South. Inst. Min. Metall. 1990, 21, 615-621.

8. Yang, J.G.; Wu, Y.T. A hydrometallurgical process for the separation and recovery of antimony. Hydrometallurgy 2014, 143, 68-74. [CrossRef]

9. Mahlangu, T.; Gudyanga, F.P.; Simbi, D.J. Reductive leaching of stibnite $\left(\mathrm{Sb}_{2} \mathrm{~S}_{3}\right)$ flotation concentrates using metallic iron in a hydrochloric acid medium II: Kinetics. Hydrometallurgy 2007, 88, 132-142. [CrossRef]

10. Xie, Z.F.; Li, B.; Liu, W.L.; Li, H.; Jiang, C.J.; Huang, H.F. A new process for preparation of qualified antimony white from jamesonite. Min. Metall. Eng. 2015, 35, 80-84.

11. Wang, Q.M.; Guo, X.Y.; Tian, Q.H.; Jiang, T.; Chen, M.; Zhao, B.J. Effects of Matte grade on the distribution of minor elements $(\mathrm{Pb}, \mathrm{Zn}, \mathrm{As}, \mathrm{Sb}$, and $\mathrm{Bi})$ in the bottom blown copper smelting process. Metals 2017, 7, 502. [CrossRef]

12. Wang, Q.M.; Guo, X.Y.; Tian, Q.H.; Chen, M.; Zhao, B.J. Reaction mechanism and distribution behavior of arsenic in the bottom blown copper smelting process. Metals 2017, 7, 302. [CrossRef]

13. Liu, W.; Luo, H.L.; Qing, W.Q.; Zheng, Y.X.; Yang, K.; Han, J.W. Investigation into oxygen-enriched bottom-blown stibnite and direct reduction. Metall. Mater. Trans. B 2014, 45, 1281-1290. [CrossRef]

14. Padilla, R.; Chambi, L.C.; Ruiz, M.C. Antimony production by carbothermic reduction of stibnite in presence of lime. J. Min. Metall. Sect. B-Metall. 2014, 50, 5-13. [CrossRef]

15. Padilla, R.; Aracena, A.; Ruiz, M.C. Kinetics of stibnite $\left(\mathrm{Sb}_{2} \mathrm{~S}_{3}\right)$ oxidation at roasting temperatures. J. Min. Metall. Sect. B-Metall. 2014, 50, 127-132. [CrossRef]

16. Smirnov, M.P. Direct smelting of lead at low temperature. Nonferr. Met. 1990, 46, 34-36.

17. Efim, V.M. Low temperature smelting of lead metallic scrap. Erzmetall 2000, 53, 85-89. 
18. Kokoro, I.; Shu, Y.; Masafumi, M. Phase relation and thermodynamic properties of $\mathrm{NaCl}_{-} \mathrm{Na}_{2} \mathrm{CO}_{3}$ system as a basic system for secondary fly ash incineration processes of municipal wastes. Mater. Trans. 2001, 42, 2480-2486.

19. Olivarea, R.I.; Chen, C.L.; Wright, S. Thermal stability of molten lithium-sodium-potassium carbonate and influence of additives on the melting point. J. Sol. Energy Eng. 2012, 134, 041002. [CrossRef]

20. Wang, T.; Mantha, D.; Reddy, R.G. Thermal stability of the eutectic composition in $\mathrm{LiNO}_{3}-\mathrm{NaNO}_{3}-\mathrm{KNO}_{3}$ ternary system used for thermal energy storage. Sol. Energy Mater. Sol. Cells 2012, 100, 162-168. [CrossRef]

21. Zhao, C.Y.; Wu, Z.G. Thermal property characterization of a low melting-temperature ternary nitrate salt mixture for thermal energy storage systems. Sol. Energy Mater. Sol. Cells 2011, 96, 3341-3346. [CrossRef]

22. Ye, L.G.; Tang, C.B.; Chen, Y.M.; Yang, S.H.; Yang, J.G.; Zhang, W.H. One-step extraction of antimony from low-grade stibnite in Sodium Carbonate e Sodium Chloride binary molten salt. J. Clean. Prod. 2015, 93, 134-139. [CrossRef]

23. Chen, Y.M.; Ye, L.G.; Tang, C.B.; Yang, S.H.; Tang, M.T.; Zhang, W.H. Solubility of Sb in binary $\mathrm{Na}_{2} \mathrm{CO}_{3}-\mathrm{NaCl}$ molten salt. Trans. Nonferr. Met. Soc. China 2015, 25, 3146-3151. [CrossRef]

24. Jun, Y.; Katsunari, O.; Koichi, A. Thermodynamic assessment of the $\mathrm{KCl}-\mathrm{K}_{2} \mathrm{CO}_{3}-\mathrm{NaCl}_{-} \mathrm{Na}_{2} \mathrm{CO}_{3}$ system. Calphad 2007, 31, 155-163.

25. Lu, W.Y.; Zeng, C.L. Preparation of cohesive graphite films by electroreduction $\mathrm{Cf}_{3}{ }^{2-}$ in molten $\mathrm{Na}_{2} \mathrm{CO}_{3}-\mathrm{NaCl}$. Surf. Coat. Technol. 2012, 206, 4287-4292.

26. Jun, Y.; Daisuke, M.; Koichi, A.; Youji, Y.; Hiroshi, Y. Strength of salt core composed of alkali carbonate and alkali chloride mixtures made by casting technique. Mater. Trans. 2007, 48, 1034-1041.

27. Kim, J.W.; Lee, H.E. Thermal and carbothermic decomposition of $\mathrm{Na}_{2} \mathrm{CO}_{3}$ and $\mathrm{Li}_{2} \mathrm{CO}_{3}$. Metall. Mater. Trans. B 2001, 32, 17-24. [CrossRef]

28. Lewis, A.E.; Beautment, C. Prioritising objectives for waste reprocessing: A case study in secondary lead refining. Waste Manag. 2002, 22, 277-285. [CrossRef]

29. Ye, L.G.; Tang, C.B.; Chen, Y.M.; Yang, S.H.; Tang, M.T. The thermal physical properties and stability of the eutectic composition in a $\mathrm{Na}_{2} \mathrm{CO}_{3}-\mathrm{NaCl}$ binary system. Thermochim. Acta 2014, 596, 14-20. [CrossRef]

30. Brain, I.; Knacke, O.; Kubaschewski, O. Thermochemical Properties of Inorganic Substance, 1st ed.; Springer: New York, NY, USA, 1972. 